DOI: $10.30519 /$ ahtr. 814822

Advances in Hospitality and Tourism Research (AHTR)

\title{
PREDICTORS AND OUTCOMES OF SUCCESSFUL LOCALIZATION IN THE AVIATION INDUSTRY: THE CASE OF OMAN
}

\author{
Nasser A. ALKATHIRI \\ University of Technology and Applied Sciences- Salalah, Oman \\ ORCID: 0000-0001-9494-7366 \\ Ahmed Mohamed ELBAZ ${ }^{1}$ \\ University of Technology and Applied Sciences- Salalah, Oman $\mathcal{E}$ \\ University of Sadat City, Egypt \\ ORCID: 0000-0002-3106-7182 \\ Iqtidar SHAH \\ Department of Business Administration, Yorkville University, Canada \\ ORCID: 0000-0002-3761-0043

\section{Mohammad SOLIMAN} \\ University of Technology and Applied Sciences- Salalah, Oman $\mathcal{E}$ \\ Fayoum University, Egypt \\ ORCID: 0000-0002-9359-763X
}

\begin{abstract}
Localization has encountered substantial focus in academia as well as practice; however, scarce studies have empirically examined this theme within tourism-related sectors in Oman, including the aviation sector. That is why the purpose of this paper is to develop and test an integrated model of the key predictors and outcomes of successful localization within the aviation industry. It also evaluates the mediating role of knowledge sharing ability between human resources development (HRD) practices and localization as well as the moderating effect of organizational commitment on the link between localization and firm performance. This paper is based on primary data collected from 194 employees operating in the national aviation sector in Oman. Based on PLS-SEM, the results indicated that HRD practices (i.e., training, performance appraisal, and rewards) have a positive impact on expatriates' ability to share knowledge with national staff, and thus positively
\end{abstract}

Article History Received 23 October 2020

Revised 19 April 2021

Accepted 24 April 2021

Published online 5 May 2021

\section{Keywords}

localization HRD practices knowledge sharing organizational commitment firm performance aviation sector ${ }^{1}$ Address correspondence to Ahmed Mohamed Elbaz (PhD), University of Technology and Applied
Sciences - Salalah, Oman \& University of Sadat City, Egypt. E-mail: ahmedelbaz.sal@cas.edu.om 
impact the localization success. Additionally, the firm's performance is positively influenced by successful localization. Knowledge sharing does not mediate the link between HRD practices and successful localization, but the results confirmed the interactive impact of organizational commitment on the direct connection between localization and performance. The findings contribute significantly to the research community and provide practical guidelines and managerial implications.

\section{INTRODUCTION}

Recent decades have experienced some economic and financial crises that substantially influenced the aviation industry in global regions including the Middle East region (Harvey \& Turnbull, 2009). The Gulf Cooperation Council (GCC), a sub-region of the Middle East comprising 6 nations (i.e., Saudi Arabia, Oman, Kuwait, the UAE, Qatar and Bahrain), are considered one of the hardest-hit regions affected by such crises, as their economies depend heavily on oil (Alaref et al., 2018; Alkathiri \& Soliman, 2020). For instance, the economies of the GCC countries encountered a significant decline due to the sharp collapse in oil prices in 2015 (GCC-STAT, 2018). Unexpectedly, the GCC nations have experienced a binary shock due to the outbreak of Covid-19 pandemic, which markedly affected economic and socio-cultural systems around the world (Hassan \& Soliman, 2021; Sigala, 2020), as well as the new breakdown in oil prices in 2020. Therefore, governments in these countries are challenged to take the necessary actions linked to the economic recession and the incessant slump in oil prices (Arezki et al., 2020).

One the contrary, the labour market in the GCC nations is characterized by a huge number of expatriates working in various industries and sectors (Harry, 2007; National Center for Statistics and Information, 2019), along with a high unemployment rate for national labour (Karam, 2017). In addition, compensation packages and wages of expatriates are much higher and costly compared to those of national workers (Wong \& Law, 1999), and the success rate of expatriates in tasks and responsibilities they undertake is not usually higher (Toh \& DeNisi, 2007). This represents a further decisive challenge to these countries, especially in times of financial and economic crises.

With the escalating concern related to these challenges, there is a crucial call to effectively implement crisis response policies and strategies to overcome these economic difficulties and manage them in a proper 
manner. With regard to localization, it refers to the replacement of expatriate workforce with host country nationals (Potter, 1989), and is considered a suitable strategic approach for many reasons (Wong \& Law, 1999). One of the most important reasons is that salaries and compensation packages of citizens are lower and less costly than expatriates' payments (Wong \& Law, 1999). Moreover, localization can enhance the decision making-power of the locals and grants them greater job advancement chances (Hitotsuyanagi-Hansel et al., 2016).

The current paper especially investigates the localization subject within the context of tourism in Oman. The country has its own policy of localization, called 'Omanization', deployed in several industries and sectors including the tourism sectors, as a suitable policy to face the economic challenges and to empower the local employment (Al-Lamki, 2005). Consequently, Omanization has experienced a growing attention and consideration in academia in various domains and contexts in Oman. However, limited studies have yet explored the Omanization topic among tourism-related sectors. To be more precise, there is no study examining the key issues concerning the Omanization policy within the Omani aviation sector.

With respect to this limitation, two major questions are raised: 1) What are the most crucial determinants of successful localization in the Omani aviation industry? 2) What are the main benefits of successful localization among the aviation sector in Oman? As a result, the present paper developed and examined an integrated framework of the essential predictors and outcomes of Omanization within the aviation sector in Oman, as one of the leading GCC countries. The proposed framework combines some crucial constructs that are closely interrelated with the Omanization context as follows: human resources development (HRD) practices (predictors); knowledge sharing (predictor and mediator variable); organizational commitment (moderator variable); and firm performance (outcome variable).

Due to the aforementioned issues, the current research focuses on five main objectives: (a) to examine the impact of HRD practices (i.e., training, performance evaluation, and rewards) on expatriates' ability to share knowledge with local staff; (b) to investigate the effect of knowledge sharing on successful localization; (c) to test the influence of successful localization on firm performance; (d) to evaluate the mediation role of knowledge dissemination on the connection between HRD practices and localization; and (e) to assess the moderation impact of organizational 
commitment on the direct path between successful localization and firm performance.

The findings of the current paper have substantial contributions concerning both academic as well as practical aspects. First, this research contributes to the literature on tourism by assessing the main antecedents and consequences of effective localization in the aviation sector, specifically in the Middle East region as well as GCC countries. Secondly, it extends to the few prior studies that investigated the issue of localization in the field of tourism in the GCC countries, especially in Oman. Third, this paper analysed the indirect effect of knowledge sharing between HRD practices and localization, which will provide a clear view of the suitable HR strategies and procedures required to transfer knowledge from expatriates to the local workforces to successfully complete the process of localization. Fourth, this article evaluates the moderating impact of organizational commitment between localization and firm performance, which will present solid outlines on how the direct impact of localization on performance can be affected under different situations of organisational commitment in the aviation industry in Oman. Finally, it produces practical guidelines and managerial implications for concerned policymakers and managers of tourism-related businesses (i.e., airlines) in Oman concerning the key issues connected with the deployment of localization (Omanization) in an effective way.

The remainder of the paper has been structured as follows: A brief account of the existing literature related to the topic, is presented in section 2 followed by an illustration of the conceptual framework and hypothesis in section 3. Section 4 describes the methodology adopted in the paper, while the results and discussion are presented in section 5 . The conclusion is demonstrated in section 6 with some policy implications.

\section{LITERATURE REVIEW}

Localization is an emerging issue which is defined in the literature from various perspectives. Potter (1989) defined localization as the practice of replacing expatriates with locals who have the capabilities to perform as efficient as expatriate staff (Law et al., 2009). According to Pegram et al. (2018), localization within the HR literature refers to the replacement of expatriate management staff by competent local people. Governments in some countries have employed several strategies and policies to replace expatriates with nationals (Mellahi \& Al-Hinai, 2000) including education 
and training of the native workforce coupled with government tools of quotas, incentives, and partnership programs for private sector organisations (Williams, 2014). Consequently, localization is considered a great challenge for many governments and international companies, as the number of expatriate employees has increased with the global business expansion, and thus replacing them with local staff is a major concern for multinational companies (Harry, 2007) including international tourism enterprises (Liu, 2004; Wang, 2016; Wong \& Law, 1999). For example, Chan et al. (2016a) reported that the high payments and rewards to expatriate employees in China's tourism and hospitality industry have forced these companies to localise their workforce. Lasserre and Ching (1997) also argued that cost reduction is one of the main objectives of localization.

Localization is an important approach from a long-term perspective, in which local staff influences strategic decisions regarding products, operations, marketing, structure, human resource management and overseas venture success (Gomez \& Sanchez, 2005). Law et al. (2004) reported that local managers have a deep understanding of the people and culture of the host country. Bartlett and Ghosal (2002) stated that localization helps an organisation to adapt their respective services to a particular language, culture and desired local look-and feel. However, the major problem in achieving a successful localization is the lack of skills and experience of natives. In this vein, Suliman and Al-Junaibi (2010) indicated that nationals do not have experience or skills to effectively replace the expatriate workforce in terms of productivity and performance. Therefore, it is the expatriates drive to transfer knowledge to the local staff is the main antecedent in achieving successful localization (Selmer, 2004). Law et al. (2004) studied four practices of HR (training, evaluation, rewards, and repatriation) as key elements that lead to successful localization. Previous studies have focussed on the antecedents of localization (Al-Hamadi et al., 2007; Budhwar et al., 2002; Law et al., 2009). However, the literature on such links remains inconclusive.

The literature on localization has focussed primarily on two main areas: the importance of localization in relation to global multinational enterprises (Selmer, 2004) and factors that contribute to achieving successful localization (Fryxell et al., 2004). In this vein, some researchers examined the factors affecting localization in various domains and contexts. The findings of Selmer (2004) demonstrated that Western expatriate managers' willingness to train national managers is a principal antecedent of successful localization in China, whereas Fryxell et al. (2004) indicated that planning and expatriates' choice are major predictors of localization 
success in Chinese multinational companies. In addition, Law et al. (2009) investigated the impact of human resources management (HRM) practices on localization of multinational enterprises in China. Nonetheless, there is a conspicuous lack of empirical investigation of tourism organizations with respect to HRD practices on knowledge sharing and localization. In addition, the literature on aviation industry is still limited (Bandeira et al., 2014; Correia et al., 2008). More particularly, there are few studies concerning HRD practices within the aviation industry (Appelbaum \& Fewster, 2003). Furthermore, as far as the authors are concerned, there is no research examining the causal relationships between HRD practices (training, performance appraisal, and rewards), knowledge sharing and localization in the aviation industry in the Middle East region, especially in Oman.

Moreover, the connection between effective localization and organization performance has been studied in previous studies (e.g., Hitotsuyanagi-Hansel et al., 2016; Law et al., 2009; Reiche, 2007), nonetheless, the impact of localization of performance from the perspective of tourism organizations has not been investigated. To be more precise, the influence of Omanization on the performance of the aviation sector has yet to be studied. Furthermore, some scholars tested the relationship between organizational commitment and performance. For instance, Jaramillo et al. (2005) conducted a meta-analysis on prior studies of fourteen nations and revealed that organizational commitment positively and significantly impacted job performance of sales staff. In addition, job performance is significantly influenced by organizational commitment, which consequently moderates the link between job stress and performance (Jamal, 2011). According to Hitotsuyanagi-Hansel et al. (2016), few studies examined the connection between localization and work attitudes of local employees. Additionally, no research work assessed the moderation role of organizational commitment on the direct association between localization and firm performance in the aviation sector.

\section{Omanization}

Oman is a member of the GCC that is featured with a strong economy that depends mainly on oil exports (Harry, 2007). According to Behrendt et al. (2009), most of the financial markets in all regions have substantially decreased because of the global financial crisis in 2008; however, the effect on economies of the GCC nations has been comparatively limited due to the huge part to surplus liquidity from the oil boom witnessed. This reflects the fact that the states of GCC continued to import skilled and well-qualified 
expatriate employees (Harry, 2007). With regard to Oman, due to the huge amount of oil revenue generated in seventies, the government initiated mega infrastructure development programs for which expatriates were recruited as the local labour market was lacking (Moideenkutty et al., 2016). After two decades of oil exploration and massive oil enterprises, the government took the initiative to promote localization plans (Al-Lamki, 2005). The localization plan called Omanization, was introduced in 1988 aimed to replace expatriate workforce with trained Omani personnel. This policy is essentially deployed to overcome the low unemployment rates for Omani nationals and to improve the level of self-reliant in human resources in several fields. Successful localization should be considered as one of the main challenges for many governments and international companies in the GCC countries (Harry, 2007) including Oman. Therefore, the Omani government set quotas for various industries to determine the percentage of Omani to foreign workers (Goby \& Alhadhrami, 2020). However, the success of these plans was limited as $85 \%$ of the workforce in private sectors is occupied by expatriates (Al-Lamki, 2005). Previous studies attributed the failure of localization deployment to the lack of skilful local workers or the local workers are more expensive (Al-Waqfi \& Forstenlechner, 2010). To cover the skill gap, the Omani government focused on training and education (Fan et al., 2013; Kaltenborn et al., 2008). The other approach is to establish a quota for local in the private sector job. Recently, Oman's vision for the future, "Oman 2040", has been developed in which jobs target in the private sector was set at $40 \%$ for Omanis (Vision 2040, n.d). "The tourism sector is predicted to employ more than 500,000 people by 2040, with an estimated 75 percent of those being Omani nationals" (Oman Observer, 2018). In addition, with the aim to decentralize the governmental decisions and establish a leaner framework for the public sector that fits with the governance aims of Oman's Vision 2040, the number of ministries was reduced (Oliver, 2020). For instance, the Ministry of Manpower, the Ministry of Civil Service, National Centre for Employment and National Training Fund were merged into one Ministry named as the Ministry of Labour. In this regard, the Ministry of Labour in Oman announced a new strategy to reduce expatriate work force by a significant increase in fees for new licenses to recruit and to bring in expatriate manpower in some professions (Oman Observer, 2021).

With respect to the tourism industry, the Omanization percentage in tourism sector is remarkably high compared to other sectors of the Omani Economy whereas the aviation sector is the second highest sector in achieving successful localization (Khan \& Krishnamurthy, 2016). The 
Omanization rate in the travel and tourism sector was 41.1 per cent in 2017, 42.2 per cent in 2018, and 43.1 per cent in 2019, while 44.1 per cent is the target for 2020. The Omanization rate in the logistics sector was 14 percent in 2017, 16 percent in 2018 and 18 percent in 2019. It has been pegged at 20 percent in 2020. Parallel to this, the Omanization target for the industrial sector will be 35 percent in 2020, after reaching 34 percent in 2019, 33 percent in 2018, and 32.5 percent in 2017 (Times of Oman, 2019).

\section{CONCEPTUAL FRAMEWORK AND HYPOTHESES DEVELOPMENT}

This study investigates the integrated conceptual model of the major antecedents and the outcomes of localization in the Omani aviation sector based on the resource dependence theory (Law et al., 2009), which aims to expand the existing literature regarding localization by examining the effect of the three practices of HRD (i.e., training, evaluation, and rewards) on expatriates' ability to share knowledge with local staff and using knowledge sharing as a mediating variable between HRD practices and localization. In addition to testing the influence of localization on firm performance, along with the moderating role of organizational commitment. The conceptual framework is shown in Figure 1.

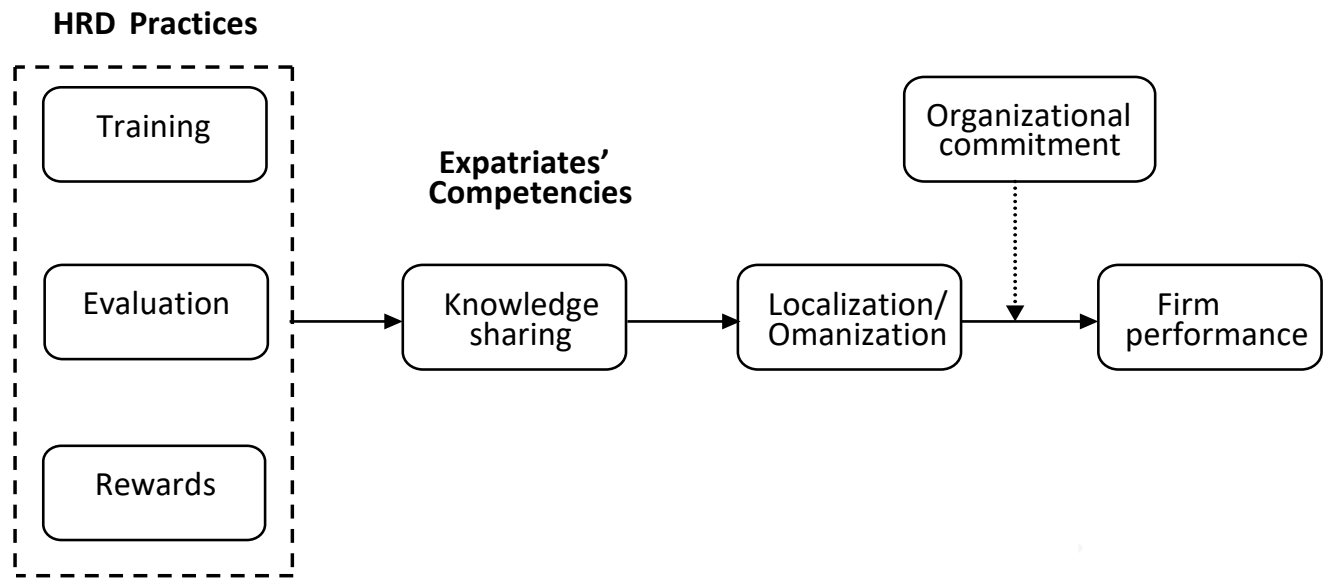

Figure 1. The conceptual framework

\section{HRD and expatriates' ability to share knowledge}

HRD practices towards localization refers to the efforts of internal resources in the home firm in facilitating the processes of localization (Law et al., 2009). More specifically, Moideenkutty et al. (2016) stated that it is a set of integral practices that focus on attracting, hiring, developing, and managing 
the local employees. Previous studies related to human resource have discussed both the importance of HRM as well as the issues related to expatriate management, particularly the high failure rate of expatriates. Moreover, some researchers have focussed on the impact of HRM practice adaptation (Chen \& Wilson, 2003). Garavan et al. (2001) demonstrated that HRD plays a vital role in improving human capital which can pave the way towards achieving a competitive advantage. In theory, this indicates the influence of HRD practices on staff development and behaviour (Law et al., 2009). These practices include, for instance; improving the skills of employees via training, enhancing the motivation of employees through rewards and employee selection and evaluation, which enables the employees to develop new ways to perform their jobs in an effective and innovative way (Moideenkutty et al., 2016). Thus, these practices have the potential to facilitate the process of localization (Law et al., 2009). For example, Harry (2007) reported that the essential method to achieving successful localization is to develop appropriate HRM practices which would promote localization. Chan et al. (2016a) stressed the importance of training in the hotels industry due to the capability to enhance local employees' understanding of the corporate cultures and strategies. Hence, providing the appropriate training to local managers in the aviation sector can cultivate the localization process (Chan et al., 2016b). In this context, the Omani government has recognised the significance of developing an effective training system to cope with the growing investment in the country's tourism sector (Bontenbal \& Aziz, 2013).

Moideenkutty et al. (2016) have concluded in their study that HR practices such as employee selection and recruitment, dedicated training for locals, a clear career pathway and rewarding have the potential to encourage successful localization. However, literature on the aviation industry is still limited (Bandeira et al., 2014; Correia et al., 2008), and there are very limited studies regarding HRD practices in the aviation industry (Appelbaum \& Fewster, 2003). Furthermore, Chan et al. (2016a) claimed that the HRD practices in the tourism and aviation industry each have their own characteristics. That is why Appelbaum and Fewster (2003) demonstrated that companies in the aviation industry should adopt effective HRD practices to manage the dynamic changes within the industry. Therefore, there is a need to investigate the impact of HRD practices such as appraisal, payments promotion and coaching in achieving successful localization.

Previous studies have used the motivations of expatriates towards localization as a key determinant factor for the success of localization 
(Selmer, 2004). This means that if expatriate employees are not motivated to transfer the knowledge to local employees, localization may not be successfully achieved. Tsang (1999) concluded that HR practices such as recruiting the right expatriates and providing effective training have the potential to enhance the ability of expatriates to share knowledge with the local staff. Consequently, this may successfully lead to localization. In addition, HR practices such as training, evaluations and rewards can be used to improve the motivation of expatriates in transferring knowledge to local employees (Hislop, 2002; Huselid, 1995). This means that the expatriate motivations towards localization will be high when the organisation provides the expatriates with rewards. Therefore, this study developed the following hypothesises:

Hypothesis 1: Training has a positive impact on expatriates' knowledge dissemination to local employees.

Hypothesis 2: Performance evaluation has a positive impact on expatriates' knowledge dissemination to local employees.

Hypothesis 3: Rewards have a positive impact on expatriates' knowledge dissemination to local employees.

\section{Expatriates' ability to share knowledge and localization}

Previous studies utilized the ability of expatriates towards localization as determining factors for successful localization (Selmer, 2010). This implies that the localization process may not be effective if the expatriates are not able or motivated to transfer their knowledge to local employees (Rogers, 1999; Wong \& Law, 1999). The lack of ability or motivation attributed by expatriates towards localization can be summarised in four reasons. First, expatriates may lack the skills required to teach the local staff, as not everyone has the ability to teach others (Chang et al., 2012). Second, even though they possess the appropriate skills to teach the local staff, expatriates might still be reluctant to share their knowledge with the local staff due to their concerns of making redundancies (Selmer, 2004). In contrast, Dutt et al. (2017) demonstrated that since expatriates view their employments as temporary, their involvement will be limited and thus reduce their motivations to share their knowledge. The fourth reason is related to the absorptive capacity of the local staff as they may not be willing or are not able to learn from the expatriates (Elbaz et al., 2018). Thus, this paper proposes the following:

Hypothesis 4: Expatriates' knowledge sharing to local employees enhances localization success. 


\section{Localization and firm performance}

Moreover, this study aims to test the influence of successful localization on the performance of the Omani aviation sector. In this regard, no research work has empirically examined how localization affects performance in the aviation sector. However, the relation between the two variables has been investigated by some scholars in different disciplines. For example, Wong and Law (1999) indicated that localization could be a proper business objective in Chinese transnational corporations for many causes such as low cost of nationals, effective business relationships by local employees, enhancing the Chinese mangers' morale, the active communication between nationals' workers and managers and the significant contribution to performance (Law et al., 2009). In addition, Reiche (2007) stated that localization could decrease the bias of ethnocentric which strengthens the disparity among expatriates and locals' employees. Law et al. (2009) argued that effective localization could lead to better performance of the company. Moreover, Hitotsuyanagi-Hansel et al. (2016) reported that enterprise success can be achieved by local workers having a higher level of effective localization. These workers are more likely to be loyal to their_organisations and consequently are more likely to avoid behaviours that would produce costs for their employers. Based on the aforementioned discussion, we made the following hypothesis:

Hypothesis 5: Successful localization has a positive impact on the firm's performance.

\section{The mediating role of expatriates' ability to share knowledge}

Including the debates of $\mathrm{H} 1$ to $\mathrm{H} 5$, the current study recognised direct relationship between HRD practices and expatriates' ability to transfer knowledge on the one hand, as well as the direct relationship between the expatriates' ability to transfer knowledge and localization. Thus, expatriates' ability to share knowledge is likely to mediate the relationship between HRD practices and successful localization. Therefore, this current study posits that:

Hypothesis 6: Expatriates' ability to share knowledge mediates the relationship between HRD practices and localization success.

\section{The moderating role of organisational commitment}

The current paper further evaluates the interactive impact of organizational commitment on the relation between successful localization and 
performance of the aviation sector in Oman. According to Mowday et al. (1979), organizational commitment is the relative strength of an individuals' identification with and involvement in a particular organization. Organizational commitment has been widely investigated in a lot of research concerning organizational behaviour due to its substantial impact on beneficial behaviours of the company such as performance and turnover of workers (Riketta, 2002). Therefore, the relationship between organizational commitment and the performance of organizations in different sectors has been examined in prior studies. For example, the study of Shaw et al. (2003) investigated the association between organizational commitment and two dimensions of job performance at two commercial banks in the UAE and found that affective commitment was not significantly correlated with the overall job performance. Additionally, Chen et al. (2006) indicated that there is a positive connection between organizational commitment and job performance of accounting professionals in both Taiwan and the USA. Moreover, the findings of Suliman and Al Kathairi (2013), illustrated that there is a significant connection between both affective and continues organizational commitment and performance of employees of three governmental organizations in the UAE. Furthermore, Fu and Deshpande (2014) revealed that performance of workers operating at a Chinese insurance company is positively affected by organizational commitment. One the contrary, Hitotsuyanagi-Hansel et al. (2016) indicated that localization positively affects organizational commitment. They also revealed that organizational commitment fully mediates the link between localization and employees' turnover intention for Chinese white-collar working at manufacturing, technology, and service sectors. However, the moderation role of organizational commitment on the direct connection between successful localization and firm's performance has not been investigated yet, within the aviation industry in GCC countries and in Oman in particular. Therefore, the following hypothesis is formulated:

Hypothesis 7: Organizational commitment moderates the link between successful localization and firm's performance.

\section{METHODOLOGY}

\section{Population, sample, and data collection}

The Omani national aviation is the most prominent example of successful Omanization (localization) besides banking (Al Lamki, 2005). Therefore, we 
selected Oman national aviation as a case study to test the current study hypothesis. There were approximately 5,315 employees, out of which 3,152 were Omani and 2,163 were expatriate employees. We distributed 500 questionnaires to the frontline employees with the expectation of $35 \%$ return. A total of 203 completed questionnaires were received, of which 194 found valid and used for this study while 9 questionnaires were found incomplete and invalid to use. Paper-based surveys were administered in November and December 2018 with the aid of two research assistants. Nevertheless, the issue with generalisation associated with convenience sampling remains accepted in contemporary literature where it is hard to access the population (Baltes \& Ralph, 2020). Based on Feild et al. (2006), non-probability sampling can contribute to the quality of the data when adequate participation levels are accomplished. Therefore, the current study adopted non-probability convenience sampling due to the fundamental features of the aviation sector and the pragmatism required to entice their involvement.

\section{Measurement instruments}

To measure localization, the study adopted the seven items measures of Law et al.'s (2009) study. We used four items of Chang et al. (2012) to measure the expatriates' ability to disseminate knowledge. These four items considered the knowledge dissemination to local staff. HRD practices were divided into three groups measured by sixteen items adopted from Law et al. (2009). The first group considers local staff training, which was measured by eight items. The second group evaluation, which was measured by four items. The third group considered rewards related to localization, which was measured by adopting four items from Law et al. (2009). To measure the firm performance, we have used Conger et al. (2000) five-item scale. Finally, organisational commitment items were borrowed from Khan et al. (2014) and Abdelhamied and Elbaz (2018).

\section{Data analysis methods}

To test the hypotheses, we used a PLS-SEM using WarpPLS 6.0 (Kock, 2017). The choice of the PLS-SEM was deemed appropriate for three key reasons. Hair et al. (2017) have recommended PLS-SEM method is used for forecasting. This method mainly focuses on clarifying the variance in variables by calculating the total disparity in the observed variables rather than just the correlations between the variables (Sarstedt et al., 2014, 2016). Moreover, Hair et al. (2011) demonstrated that the PLS-SEM enables the researchers to assess the structural model relationships that increase the $\mathrm{R}^{2}$ 
values of the measured variable while also enabling researchers to estimate the outcome of the dependent latent variables' items by measuring the Stone-Geisser $\mathrm{Q}^{2}$ values. These characteristics are significant for this study due to the focus on (1) identifying the key HRD practices explaining successful localization in the Omani context and (2) explaining employee via the interventional role of the competency of expatriates.

Finally, the PLS-SEM is highly recommended for complex models having different latent variables (Henseler et al., 2009). In the current paper, the researchers proposed an integrative model that includes seven latent variables, each with a number of indicators. Hence, PLS-SEM was used in this study as it is better suited for complex settings. In addition, PLS-SEM does not assume normality and takes into account the evaluation of two main distinctive models, namely the measurement model and the structural model. In short, Jarvis et al. (2003) indicated that the measurement model considers the association between the latent variables and their indicators, whereas the structural model considers the association between the latent variables.

\section{ANALYSIS AND RESULTS}

\section{Sample Profile}

Total 194 valid questionnaires have been used in this study. The sample characteristics (Table 1) illustrated that the employees who participated in the survey were generally $26-35$ years old (67.0\%), followed by $36-45$ years old $(20.2 \%)$. The majority of the participants were males (approx. 68\%) which is a common case in the Middle East and Arab countries where the male workforce generally dominates the workplace. Finally, about half of the participants hold a bachelor's degree $(43.8 \%)$.

Table 1. Sample Profile Characteristics

\begin{tabular}{lccccc}
\hline Age & $\mathbf{1 8 - 2 5}$ & $\mathbf{2 6 - 3 5}$ & $\mathbf{3 6 - 4 5}$ & $\mathbf{4 5 - 5 5}$ & Above 55 \\
& $10.3 \%$ & $67.0 \%$ & $20.2 \%$ & $1.5 \%$ & $0.8 \%$ \\
\hline \multirow{2}{*}{ Gender } & Male & & & Female \\
& $67.8 \%$ & & $32.2 \%$ & \\
\hline \multirow{2}{*}{ Education } & Bachelor's degree & Diploma & Master's degree & Doctorate Degree & Others \\
& $43.8 \%$ & $38.1 \%$ & $12.9 \%$ & $1.5 \%$ & $3.6 \%$ \\
\hline
\end{tabular}

\section{Validity and Reliability}

This study tested both the validity and reliability for all constructs, and this was performed by assessing the measurement suitability of the constructs 
implemented in current paper (i.e., the measurement model). The reliability of latent variables was tested through both composite and Cronbach's Alpha coefficients (Table 2). On the contrary, the validity of latent variables was measured through the indicators' loading (see appendix); the Average Variance Extracted (AVE) was tested to measure the convergent validity and the square roots of AVE was tested to assess the discriminant validity (Table 3). The Variance Extracted Factor (VIF) was also checked for all the variables to examine collinearity issues (Table 2).

Table 2. Construct Coefficients

\begin{tabular}{lcccc}
\hline Variables & Composite Reliability & Cronbach's Alpha & AVE & VIF \\
\hline Organizational commitment & 0.889 & 0.923 & 0.666 & 3.495 \\
Training & 0.937 & 0.921 & 0.681 & 3.350 \\
Performance evaluation & 0.870 & 0.801 & 0.626 & 2.560 \\
Rewards & 0.897 & 0.847 & 0.686 & 1.589 \\
Knowledge sharing & 0.899 & 0.850 & 0.690 & 2.450 \\
Firm performance & 0.944 & 0.925 & 0.770 & 2.150 \\
Localization & 0.912 & 0.883 & 0.633 & 2.929 \\
\hline
\end{tabular}

Table 3. Squared Roots of AVE

\begin{tabular}{llcccccc}
\hline & $\mathbf{1}$ & $\mathbf{2}$ & $\mathbf{3}$ & $\mathbf{4}$ & $\mathbf{5}$ & $\mathbf{6}$ & $\mathbf{7}$ \\
\hline 1. Organizational commitment & $(0.825)$ & & & & & & \\
2. Training & 0.770 & $(0.852)$ & & & & & \\
3. Performance evaluation & 0.546 & 0.593 & $(0.791)$ & & & & \\
4. Rewards & 0.266 & 0.326 & 0.533 & $(0.828)$ & & & \\
5. Localization & 0.704 & 0.693 & 0.684 & 0.427 & $(0.796)$ & & \\
6. Firm performance & 0.632 & 0.597 & 0.556 & 0.470 & 0.618 & $(0.878)$ & \\
7. Knowledge sharing & 0.316 & 0.312 & 0.432 & 0.364 & 0.305 & 0.391 & $(0.831)$ \\
\hline
\end{tabular}

Based on Mackenzie et al.'s (2011) approach, a minimum value of 0.7 for both Composite Reliability and Cronbach's Alpha coefficients were found thus showing good reliability for constructs (Table 2). Correspondingly, an appropriate level of validity and reliability for all latent variables used in this current paper has been established (Tables 2 and 3). In this way, a suitable convergent validity was found as all AVEs achieve a minimum value of 0.5 and all indicators' loadings greater than a threshold value of 0.5 (Hair et al., 2017).

Table 3 illustrates that the AVEs of all constructs are greater than that of any other correlations involving the latent variable thus signifying appropriate discriminant validity (Lowry \& Gaskin, 2014). Ultimately, Table 2 shows that the VIF values of all latent variables were less than 5 , 
therefore demonstrating the absence of both common methods bias and multicollinearity (Kock \& Lynn, 2012).

\section{Structural Relationship Model}

With the assessment of the measurement model which established the validity and reliability of latent variables used in the present study, the analysis of the structural relationship model can subsequently be undertaken. Therefore, Figure 2 presents both the path coefficients $(\beta)$ and the $\mathrm{p}$ values of the present research model.

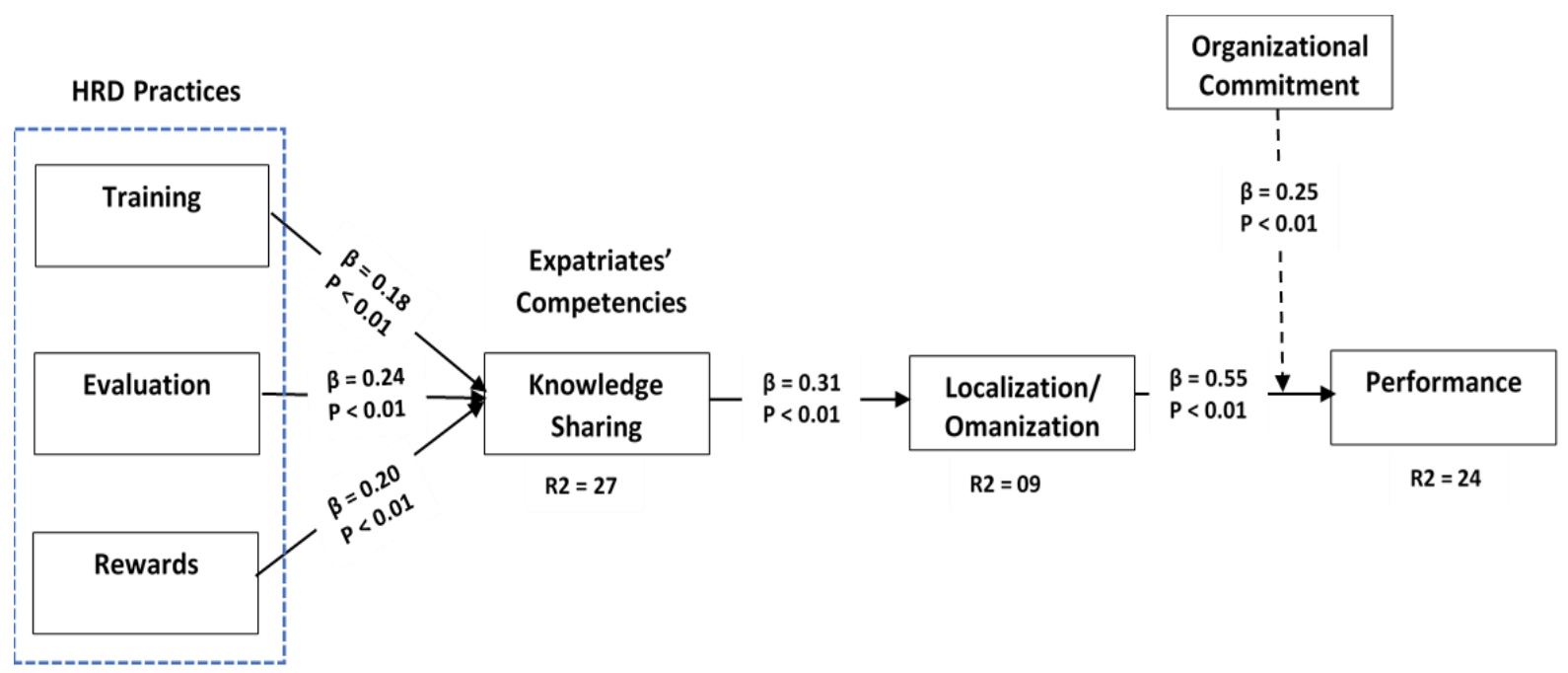

Figure 2. Coefficients $(\beta)$ and the $p$ values of the model

Results showed that training had a significant influence on knowledge sharing ability $(\beta=0.18$ and $\mathrm{P}<0.01)$. Furthermore, performance evaluation had a significant influence on knowledge sharing ability $(\beta=0.24$ and $\mathrm{P}<0.01$ ), and finally we found rewards hold a moderate positive effect on expatriates' ability to share knowledge with local employees $(\beta=0.20$ and $\mathrm{P}<0.01$ ). Hence, Hypotheses 1, 2, and 3 are accepted (see Figure 2). Considering the direct influence of expatriates' ability to share knowledge on successful localization, a strong positive influence was found $(\beta=0.31$ and $\mathrm{P}<0.01$ ). Therefore, Hypothesis 4 is also accepted. Finally, the findings revealed that localization holds a strong positive impact on firm performance $(\beta=0.55$ and $\mathrm{P}<0.01)$, supporting Hypothesis 5 .

An indirect analysis was applied to determine the intervening role of expatriates' ability to share knowledge in the relationship between the HRD practices and localization success. The results of the present study demonstrate that expatriates' ability has no mediating link between HRD practices (training, performance evaluation and rewards) and localization success. Thus, Hypotheses 6 is rejected. 
Table 4. Indirect Relationship Results

\begin{tabular}{|c|c|c|c|}
\hline \multirow[t]{2}{*}{ Paths } & \multicolumn{2}{|c|}{ Significance } & \multirow[t]{2}{*}{ Outcome } \\
\hline & $\begin{array}{l}\text { Direct } \\
\text { effect }\end{array}$ & $\begin{array}{c}\text { Indirect Effect via } \\
\text { Ability to share } \\
\text { knowledge }\end{array}$ & \\
\hline $\begin{array}{l}\text { Training on Localization success via } \\
\text { expatriates' ability to share knowledge }\end{array}$ & $P=0.02$ & $p<0.13$ & $\begin{array}{c}\text { Not } \\
\text { Mediated }\end{array}$ \\
\hline $\begin{array}{l}\text { Performance evaluation on Localization success } \\
\text { via expatriates' ability to share knowledge }\end{array}$ & $p<0.01$ & $p<0.07$ & $\begin{array}{c}\text { Not } \\
\text { Mediated }\end{array}$ \\
\hline $\begin{array}{l}\text { Rewards on Localization success via } \\
\text { expatriates' ability to share knowledge }\end{array}$ & $p<0.01$ & $p<0.11$ & $\begin{array}{c}\text { Not } \\
\text { Mediated }\end{array}$ \\
\hline
\end{tabular}
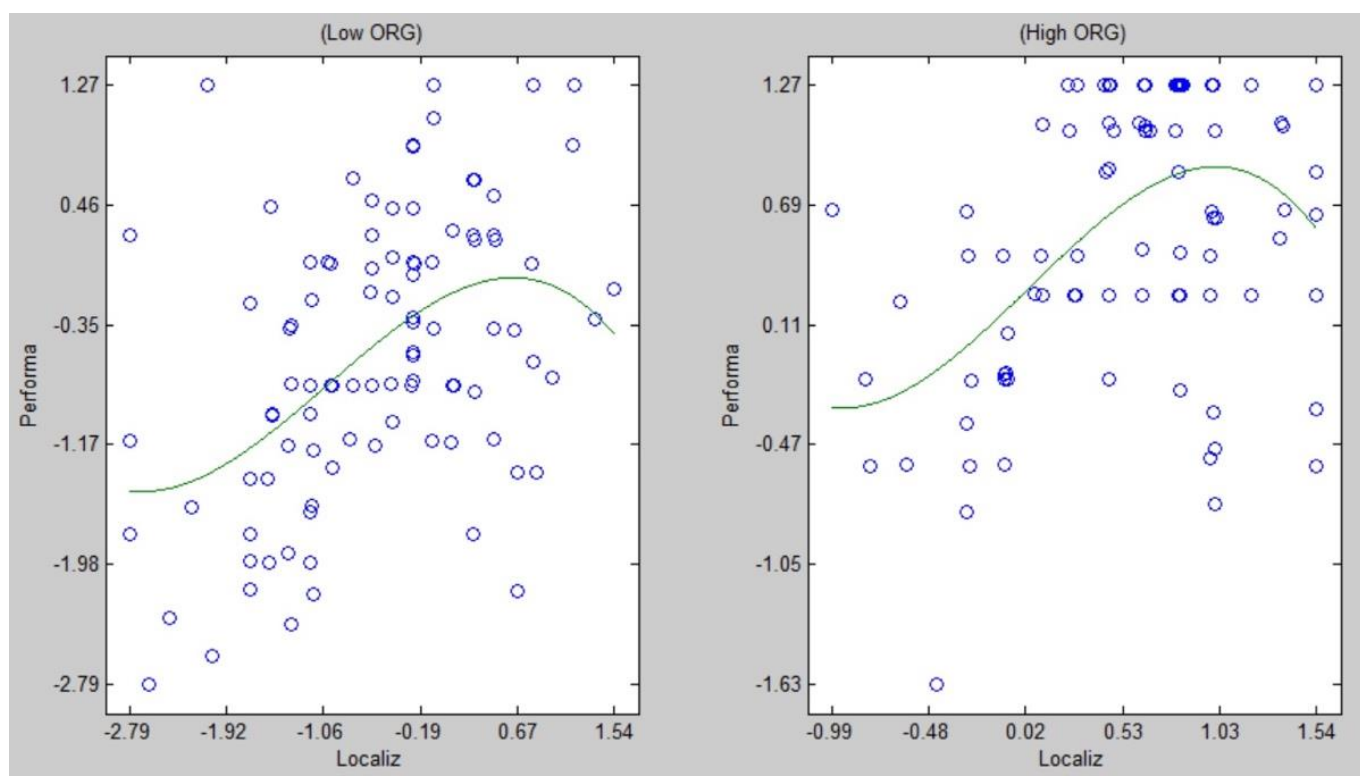

Figure 3. The Moderating Role of Organizational Commitment

We assumed organizational commitment would have a moderating effect on the association between successful localization and firm performance. In order to assess the potential for moderating effect, successful localization as a predictor and organizational commitment as a moderator were multiplied to generate an interaction construct (successful localization $\times$ organizational commitment) to predict firm performance. The predicted standardized path coefficient for the impact of the moderator on firm performance $(\beta=0.25 ; \mathrm{p}<0.01)$ is significant (see Figure 2 and Figure $3)$. Thus, organizational commitment reinforced the positive link between successful localization and firm performance (see Figure 2 and Figure 3 ) and hence, Hypothesis 7 is accepted.

In general, the HRD practices in the present study explains $27 \%$ of the expatriates' ability to transfer knowledge, $9 \%$ of the ability for successful localizations, whereas $24 \%$ for firm performance. In accordance with 
Sarstedt et al (2014) for the assessment of the predictive validity of the present model, a blindfolding method with an omission distance of 7 was implemented. This generated cross-validated redundancy $\left(\mathrm{Q}^{2}\right.$ StoneGeisser) values for the four dependent variables that are greater than zero (expatriates' ability: 0.27; localization success: 0.10; firm performance 0.24), thereby indicating the predictive validity of the research model.

\section{DISCUSSION OF FINDINGS}

Results show that training had a significant influence on the dissemination of knowledge followed by performance evaluation. Rewards had a moderately low effect. This signifies that all the three indicators successfully enhance expatriates' competencies to transfer knowledge to local employees. These results are consistent with prior studies. Salim et al. (2011) claimed that in order to improve expatriate managers' knowledge dissemination to local employees, the firm needs to maintain a high level of support. Furthermore, HRD practices such as training, evaluation and rewards enrich the expatriates' knowledge dissemination to local employees (Hislop, 2002; Huselid, 1995; Moideenkutty et al., 2016). In addition, training had a significant impact on the ability of expatriates to transfer knowledge. This aligns with the findings of Tsang (1999) and Moideenkutty et al. (2016) where a significant association between training and the competency of expatriates has been found. We argued that with the increase in training, the capabilities of expatriates in transferring knowledge to local employees becomes higher, thus it is likely to conclude that training has a positive impact on expatriates' ability.

Considering the direct influence of the expatriates' ability in transferring knowledge on the success for localization, results suggested that expatriates' ability was found to have a positive influence on successful localization. This implies that if expatriates do not disseminate knowledge to local employees, localization may not succeed in the Omani aviation sector (Chang et al., 2012).

The results show that expatriates' ability to transfer knowledge had no meditating role in the association between HRD practices and localization. Therefore, it can be claimed that HRD practices may not necessarily increase the expatriates' knowledge dissemination to local employees and the firm performance, unless it results in the achievement of successful localization. As for the moderating role of organisational commitment, the results of the current study indicated that the relationship 
between localization and firm performance is higher when the organisation has high commitment towards localization. This result indicates that originations that are supportive with enhancing their local staff effectiveness, have clear goals for localization and have detailed and concrete plans for localization, would help to achieve high performance.

\section{CONCLUSION}

The main aim of the current paper is to investigate the impact of HRD practices on the abilities of expatriates in transferring knowledge and firm performance. To achieve this, an integrated model was developed and tested to oversee the simultaneous influence of three diverse firm characteristics (training, performance evaluation and rewards) on the competency of expatriates' ability to transfer knowledge. The model was tested by using primary data collected from the staff of the aviation sector operating in the Sultanate of Oman. Finally, it was found that organizational commitment plays a moderating role in the direct connection between localization and performance.

These results hold significant theoretical and practical implications. Unlike numerous previous studies, not all human resource practices were relevant to the Omani aviation sector, from a theoretical perspective. This study argues that such results are due to the high percentage of successful localization that has been achieved (Khan \& Krishnamurthy, 2016). Moreover, these inconclusive findings could be related to the high frequency of training in the aviation sector which made the local employees active in seeking knowledge from expatriates, and thus positively influences the ability of expatriates to share their knowledge (Elbaz et al., 2018).

The current article contributes to the tourism literature by investigating the key predictors and outcomes of localization in tourismrelated sectors (i.e., the aviation sector) within the MENA region. This is one of the limited studies that examines the Omanization subject, particularly within the aviation sector in Oman. In addition, this study is considered the first attempt to empirically examine a comprehensive structural model, incorporating such latent constructs (HRD practices, knowledge sharing, localization, organizational commitment, and firm performance), in the MENA region, especially in Oman. Another theoretical contribution of the current paper is to evaluate the intervening impact of knowledge sharing between HRD practices and localization, within the aviation context in the 
GCC nations. Furthermore, unlike the previous studies that employed organisational commitment as an independent variable, this study investigated its moderating effect. In this regard, it confirms the positive interaction impact of organizational commitment on the direct relation between localization and performance.

In practice, these results hold significant implications for the decision-makers in air transportation in Oman, GCC, the MENA and other similar countries. Evaluation, and rewards are important antecedents towards the achievement of successful localization, which would in turn improve the overall of the aviation sector. Decision-makers are therefore urged to pay attention to such practices in order to drive the firm performance and localization success. This can be achieved by establishing effective teamwork, encouraging open communication between employers and their subordinates and building mutual trust. Moreover, it is very important to value and recognize the employees who are committed to knowledge_transfer.

Furthermore, this study considered the vital role of achieving localization in enhancing the Omani aviation sector. In this regard, the present study proved that the positive impact of HRD practices and expatriates' knowledge dissemination is attributed to the achievement of successful localization and the enhancement of firm performance. Consequently, this raises awareness of the inevitable positive impact that HRD practices should have in achieving localization as well as improving the firm performance. Furthermore, it is important for countries which have adopted the localization process to use and encourage HRD practices effectively in order to achieve localization.

Like any other studies, this paper has a number of limitations that can be handled in future studies. First, the current study did not consider the role of local employees towards achieving successful localization. Therefore, further studies are required in order to investigate the moderating role of local employees' opportunity between the competency of expatriates and localization success. In addition, due to the unavailability of expatriate percentage in each firm, this study uses subjective measures to measure localization, thus, future studies are recommended to use the objective measures for localization as in Law et al. (2009). Furthermore, this current study investigates the role of expatriate ability in knowledge dissemination, and future studies may investigate other competencies of expatriates such as their motivation and seeking opportunity (Chang et al., 2012). 


\section{ACKNOWLEDGMENT}

This research is supported by the Salalah College of Applied Sciences, University of Technology and Applied Sciences, Oman. We would like to thank the human resources in the Omani aviation sector for circulating our questionnaire. We are also grateful to our respondent aviation employees for participating in the study.

\section{REFERENCES}

Abdelhamied, H., \& Elbaz, A. (2018). Burnout in tourism and hospitality SMEs: The moderating role of organizational commitment. International Journal of Heritage, Tourism and Hospitality, 12(2), 66-82.

Alaref, J., Koettl-Brodmann, J., Onder, H., Rahman, A., Speakman, J., Beschel, R., Malik, I., Vodopyanov, A., \& Quota, M. (2018). The jobs agenda for the Gulf cooperation council countries (English). Washington, D.C.: World Bank Group. http://documents.worldbank.org/curated/en/792871524204977802/Thejobsagenda-for-the-Gulf-cooperation-council-countries

Alkathiri, N. A., \& Soliman, M. (2020). Examining foreign direct investment determinants of tourism industry in Oman and Egypt: The moderating role of investment environment. International Journal of Finance $\mathcal{E}$ Economics, 1-19. https://doi.org/10.1002/ijfe.2396

Al-Hamadi, A. B., Budhwar, P. S., \& Shipton, H. (2007). Management of Human Resources in Oman. The International Journal of Human Resource Management, 18(1), 100-113.

Al-Lamki, S. (2005). The role of private sector in Omanization: The case of the banking industry in the Sultanate of Oman. International Journal of Management, 22(2), 176188.

Al-Waqfi, M., \& Forstenlechner, I. (2010). Stereotyping of citizens in an expatriatedominated labour market: implications for workforce localization policy. Employee Relations, 32(4), 364-381.

Appelbaum, S. H., \& Fewster, B. M. (2003). Global Aviation Human Resource Management: Contemporary Compensation and Benefits Practices. Management Research News, 26(7), 59-71.

Arezki, R., Fan, R. Y., \& Nguyen, H. (2020). Coping with COVID-19 and oil price collapse in the Gulf Cooperation Council. Retrieved July 8, 2020, from https://blogs.worldbank.org/arabvoices/coping-covid-19-and-oil-pricecollapsegulf-cooperation-council

Baltes, S., \& Ralph, P. (2020). Sampling in software engineering research: A critical review and guidelines. arXiv preprint arXiv:2002.07764.

Bandeira, M. C. G. D. S., Borille, G. M. R., Maia M. C. D., \& Moser R. F. (2014). Key indicators that affect the perception of service quality in critical airport areas of passenger boarding. Journal of Transport Literature, 8(4), 7-36.

Bartlett, C., \& Ghoshal, S. (2002). Managing Across Borders. Cambridge, MA: Harvard Business Press.

Behrendt, C. H., Haq, T., \& Kamel, N. (2009). The impact of the financial and economic crisis on Arab states: considerations on employment and social protection policy responses. International Labour Office, Beirut. 
Bontenbal, M., \& Aziz, H. (2013). Oman's tourism industry: student career perceptions and attitudes. Journal of Arabian Studies, 3(2), 232-248.

Budhwar, P. S., Al-Yahmadi, S., \& Debrah, Y. (2002). Human Resource Development in the Sultanate of Oman. International Journal of Training and Development, 6(3), 198-215.

Chan, D., Ye, T., \& Xu, H. (2016a). Localization of senior managers of international luxury hotels in China: the current situation and influencing factors. Journal of China Tourism Research, 12(1), 126-143.

Chan, D., Ye, T., \& Xu, H. (2016b). Culture differences and challenges in localization of senior executives of international luxury hotels in China. Journal of China Tourism Research, 12(2), 196-215.

Chang, Y. Y., Gong, Y., \& Peng, M. W. (2012). Expatriate knowledge transfer, subsidiary absorptive capacity and subsidiary. Academy of Management Journal, 55(4), 927-948.

Chen, J., Silverthorne, C., \& Hung, J. (2006). Organization communication, job stress, organizational commitment, and job performance of accounting professionals in Taiwan and America. Leadership \& Organization Development Journal, 27(4), 242-249.

Chen, S., \& Wilson, M. (2003). Standardization and localization of human resource management in Sino-foreign joint ventures. Asia Pacific Journal of Management, 20, 397-408.

Correia, A. R., Wirasinghe, S. C., \& de Barros, A. G. (2008). Overall level of service measures for airport passenger terminals. Transportation Research Part A: Policy and Practice, 42(2), 330-346.

Conger, J. A., Kanungo, R. N., \& Menon, S. T. (2000). Charismatic leadership and follower effects. Journal of Organizational Behavior: The International Journal of Industrial, Occupational and Organizational Psychology and Behavior, 21(7), 747-767.

Dutt, C. S., Harvey, W. S., \& Shaw, G. (2017). The missing voices in the perceptions of tourism: the neglect of expatriates. Tourism Management Perspectives, 26, 193-202. http://dx.doi.org/10.1016/j.tmp.2017.10.004

Elbaz, A. M., Agag, G. M., \& Alkathiri, N. A. (2018). How ability, motivation and opportunity influence travel agents: the moderating role of absorptive capacity. Journal of Knowledge Management, 22(1), 119-141.

Fan, X., Lu, Z., \& Wu, H. (2013). Current situation of rural residents' tourism: a case study in Zhejiang Province in China. Asia Pacific Journal of Tourism Research, 19(10), 11911206. http://dx.doi.org/10.1080/10941665.2013.840657

Feild, L., Pruchno, R. A., Bewley, J., Lemay Jr, E. P., \& Levinsky, N. G. (2006). Using probability vs. nonprobability sampling to identify hard-to-access participants for health-related research: Costs and contrasts. Journal of Aging and Health, 18(4), 565583.

Fryxell, G., Butler, J., \& Choi, A. (2004). Successful localization programs in China: An important element in strategy implementation. Journal of World Business, 39(3), 268283.

Fu, W., \& Deshpande, S. P. (2014). The impact of caring climate, job satisfaction, and organizational commitment on job performance of employees in a China's insurance company. Journal of Business Ethics, 124, 339-349.

Garavan, T., Gunnigle, M., \& Collins, E. (2001). Human capital accumulation: the role of human resource development. Journal of European Industrial Training, 44(5), 48-60.

GCC-STAT (2018). Economic performance and outlook for the Gulf Corporation Council (GCC) 2018. Issue No.2. Muscat - Sultanate of Oman. 
Goby, V. P., \& Alhadhrami, A. (2020). Expat or citizen? Raising the question of a potential impact of status on leader behavior. International Journal of Organizational Analysis, 28(5), 1019-1030.

Gomez, C., \& Sanchez, J. (2005). Human resource control in MNCs: a study of the factors influencing the use of formal and informal control mechanisms. The International Journal of Human Resource Management, 16(10), 1847-1861.

Hair, J. F., Ringle, C. M., \& Sarstedt, M. (2011) PLS-SEM: indeed a silver bullet. Journal of Marketing Theory and Practice, 19(2), 139-152.

Hair, J. F., Matthews, L. M., Matthews, R. L., \& Sarstedt, M. (2017). PLS-SEM or CB-SEM: updated guidelines on which method to use. International Journal of Multivariate Data Analysis, 1(2), 107-123.

Harry, W. (2007). Employment creation and 'localization': the crucial human resource issues for the GCC. The International Journal of Human Resource Management, 18(10), 132-146.

Harvey, G., \& Turnbull, P. (2009). The Impact of the Financial Crisis on Labour in the Civil Aviation Industry. Final Report. Geneva: International Labour Office.

Hassan, S. B., \& Soliman, M. (2021). COVID-19 and repeat visitation: Assessing the role of destination social responsibility, destination reputation, holidaymakers' trust and fear arousal. Journal of Destination Marketing \& Management, 19, 100495.

Henseler, J., Ringle, C. M., \& Sinkovics, R. R. (2009). The use of partial least squares path modeling in international marketing. In R. R. Sinkovics, \& P. N. Gauri (Eds.), New Challenges to International Marketing (pp. 277-319). Emerald Group Publishing Limited.

Hislop, D. (2002). Linking human resource management and knowledge management via commitment: a review and research agenda. Employee Relations, 25(2), 182-202.

Hitotsuyanagi-Hansel, A., Froese, F. J., \& Pak, Y. S. (2016). Lessening the divide in foreign subsidiaries: The influence of localization on the organizational commitment and turnover intention of host country nationals. International Business Review, 25, 569578.

Huselid, M. (1995). The impact of human resource management practices on turnover, productivity and corporate financial. Academy of Management Journal, 38(3), 635672.

Jamal, M. (2011). Job stress, job performance and organizational commitment in a multinational company: An empirical study in two countries. International Journal of Business and Social Science, 2(20), 20-29.

Jaramillo, F., Mulki, J. P., \& Marshall, G. W. (2005). A meta-analysis of the relationship between organizational commitment and salesperson job performance: 25 years of research. Journal of Business Research, 58, 705-714.

Jarvis, C. B., MacKenzie, S. B., \& Podsakoff, P. M. (2003). A critical review of construct indicators and measurement model misspecification in marketing and consumer research. Journal of Consumer Research, 30(2), 199-218.

Kaltenborn, B. P., Andersen, O., Nellemann, C., Bjerke, T., \& Thrane, C. (2008). Resident attitudes towards mountain second-home tourism development in Norway: the effects of environmental attitudes. Journal of Sustainable Tourism, 16(6), 664. https://doi.org/10.1080/09669580802159685

Karam, A. M. (2017). The Influence of Organizational Socialization and Stereotypes on Organizational Commitment and Turnover Intention: A Study on Localization in the United Arab Emirates. Unpublished doctoral dissertation, University of Wollongong, Dubai. 
Khan, N. R., Awang, M., \& Ghouri, A. M. (2014). Organizational commitment construct: Validity measure using SEM. Science International, 26(2), 897-902.

Khan, F. R., \& Krishnamurthy, J. (2016). Future proofing of tourism entrepreneurship in Oman: challenges and prospects. Journal of Work-Applied Management, 8(1), 79-94.

Kock, N. (2017). WarpPLS user manual: Version 6.0. Laredo, TX: ScriptWarp System.

Kock, N., \& Lynn, G. (2012). Lateral collinearity and misleading results in variance-based SEM: an illustration and recommendations. Journal of the Association for Information Systems, 13(7), 1-40.

Lasserre, P., \& Ching, P. (1997). Human resources management in China and the localization challenge. Journal of Asian Business, 13(4), 85-99.

Law, K., Song, L., Wong, C., \& Chen, D. (2009). The antecedents and consequences of successful localization. Journal of International Business Studies, 40, 1359-1373.

Law, K., Wong, C., \& Wang, K. (2004). An empirical test of the model on managing the localization of human resources in the People's Republic of China. Int. J. of Human Resource Management, 15(4), 635-648.

Liu, Y. (2004). Localization strategy of multinational companies in China and its impact. Contemporary Asia-Pacific Studies, 6, 29-33.

Lowry, B., \& Gaskin, J. (2014). Partial Least Squares (PLS) Structural Equation Modeling (SEM) for building and testing behavioral causal theory: when to choose it and how to use it. IEEE Transaxctions on Professional Communication, 57(2), 123-146.

MacKenzie, S. B., Podsakoff, P. M., \& Podsakoff, N. P. (2011). Construct measurement and validation procedures in MIS and behavioral research: integrating new and existing techniques. MIS Quarterly, 35(2), 293-334.

Mellahi, K., \& Al-Hinai, S. (2000). Local workers in Gulf Co-Operation Countries: assets or liabilities?. Middle Eastern Studies, 3(3), 177.

Moideenkutty, U., Murthy, Y., \& Al-Lamky, A. (2016). Localization HRM practices and financial: evidence from the Sultanate of Oman. Review of International Business and Strategy, 26(3), 431-442.

Mowday, R. T., Steers, R. M., \& Porter, L. W. (1979). The measurement of organizational commitment. Journal of Vocational Behavior, 14(2), 224-247.

National Center for Statistics and Information (2019). Total Expatriate Workers. Sultanate of Oman: Author. Retrieved November 8, 2019, from https://www.ncsi.gov.om/Pages/IndicatorDetails.aspx?ItemID=SidMRb1ylbluhY $\% 2 \mathrm{bRsukwow} \% 3 \mathrm{~d} \% 3 \mathrm{~d} 0$

Oliver, S. (2020, August 26). Major Oman Government Restructuring. Addleshaw Goddard LLP. Retrieved September 21, 2020, from https://www.lexology.com/library/detail.aspx?g=0ef01cd4-5ff0-4aa6-89ff0d44098e3d86

Oman Observer (2021, January 31). Details of the new fee hike to recruit expatriate workforce. Daily Oman Observer. Retrieved February 13, 2021, from https://www.omanobserver.om/details-of-the-new-fee-hike-to-recruit-expatriateworkforce/

Oman Observer (2018, December 16). 44pc Omanisation expected in tourism sector by 2020. Daily Oman Observer. Retrieved February 13, 2021, from https://www.omanobserver.om/tourism-sector-expected-to-drive-omanisationreport/\#: :text=As\%20per\%20the\%20statistics\%20released,41.1\%20per\%20cent\%2 0in\%202017.

Pegram, J., Falcone, G., \& Kolios, A. (2018). A review of job role localization in the oil and gas industry. Energies, 11, 2779. 
Potter, C. C. (1989). Effective localization of the workforce. Journal of European Industrial Training, 13(6), 25-30.

Reiche, B. S. (2007). The effect of international staffing practices on subsidiary staff retention in multinational corporations. International Journal of Human Resource Management, 18(4), 523-536.

Riketta, M. (2002). Attitudinal organizational commitment and job performance: a metaanalysis. Journal of Organizational Behavior, 23(3), 257-266.

Rogers, B. (1999). The expatriates in China - A dying species?. In J. Lee (ed.), Localization in China: Best Practice (pp. 34). Hong Kong: Euromoney.

Salim, M., Javed, N., Sharif, K., \& Riaz, A. (2011). Antecedents of knowledge sharing attitude and intentions. European Journal of Scientific Research, 56(1), 44-50.

Sarstedt, M., Hair, J. F., Ringle, C. M., Thiele, K. O., \& Gudergan, S. P. (2016). Estimation issues with PLS and CBSEM: where the bias lies!. Journal of Business Research, 69(10), 3998-4010.

Sarstedt, M., Ringle, C. M., Smith, D., Reams, R., \& Hair, J. F. Jr (2014). Partial Least Squares Structural Equation Modeling (PLS-SEM): a useful tool for family business researchers. Journal of Family Business Strategy, 5(1), 105-115.

Selmer, J. (2004). Expatriates' hesitation and the localization of western business operations in China. The International Journal of Human Resource Management, 15(6), 1094-1107.

Selmer, J. (2010). Staff localization and organizational characteristics: western business operations in China. Asia Pacific Business Review, 10(1), 43-57. doi:10.1080/13602380412331288800.

Shaw, J. D., Delery, J. E., \& Abdull, H. A. (2003). Organizational commitment and performance among guest workers and citizens of an Arab country. Journal of Business Research, 56, 1021-1030

Sigala, M. (2020). Tourism and COVID-19: Impacts and implications for advancing and resetting industry and research. Journal of Business Research, 117, 312-321.

Suliman, A., \& Al-Junaibi, Y. (2010). Commitment and turnover intention in the UAE oil industry. The International Journal of Human Resource Management, 21(9), 1472-1489.

Suliman, A., \& Al Kathairi, M. (2013). Organizational justice, commitment and performance in developing countries: The case of UAE. Employee Relations, 35(1), 98-115.

Times of Oman (2019, December 10). Omanisation targets for 2020 announced. Times of Oman. Retrieved February 13, 2021, from https://timesofoman.com/article/83064omanisation-targets-for-2020-announced

Toh, S., \& DeNisi, A. (2007). Host country nationals as socializing agent: A social identity approach. Journal of Organizational Behavior, 28, 281-301.

Tsang, E. (1999). The knowledge transfer and learning aspects of international HRM: an empirical study of Singapore MNCs. International Business Review, 8, 591-609.

Vision 2040 (n.d.). Preliminary Vision Document. Retrieved September 2, 2020, from https://www.2040.om/en/vision-realization-indicators/

Wang, Y. (2016). Localization of international hotel brands in China. American Journal of Industrial and Business Management, 6(09), 942-946.

Williams, J. S. (2014). An Integrated Model for Effective Localization of Human Resources in the State of Qatar: A Comparative Study of Expatriates and Nationals. Unpublished doctoral dissertation, Charles Sturt University, Australia.

Wong, C. S., \& Law, K. S. (1999). Managing localization of human resources in the PRC: a practical model. Journal of World Business, 34(1), 26-40. 


\section{APPENDIX}

\section{Confirmatory Factor Analysis (PLS Approach)}

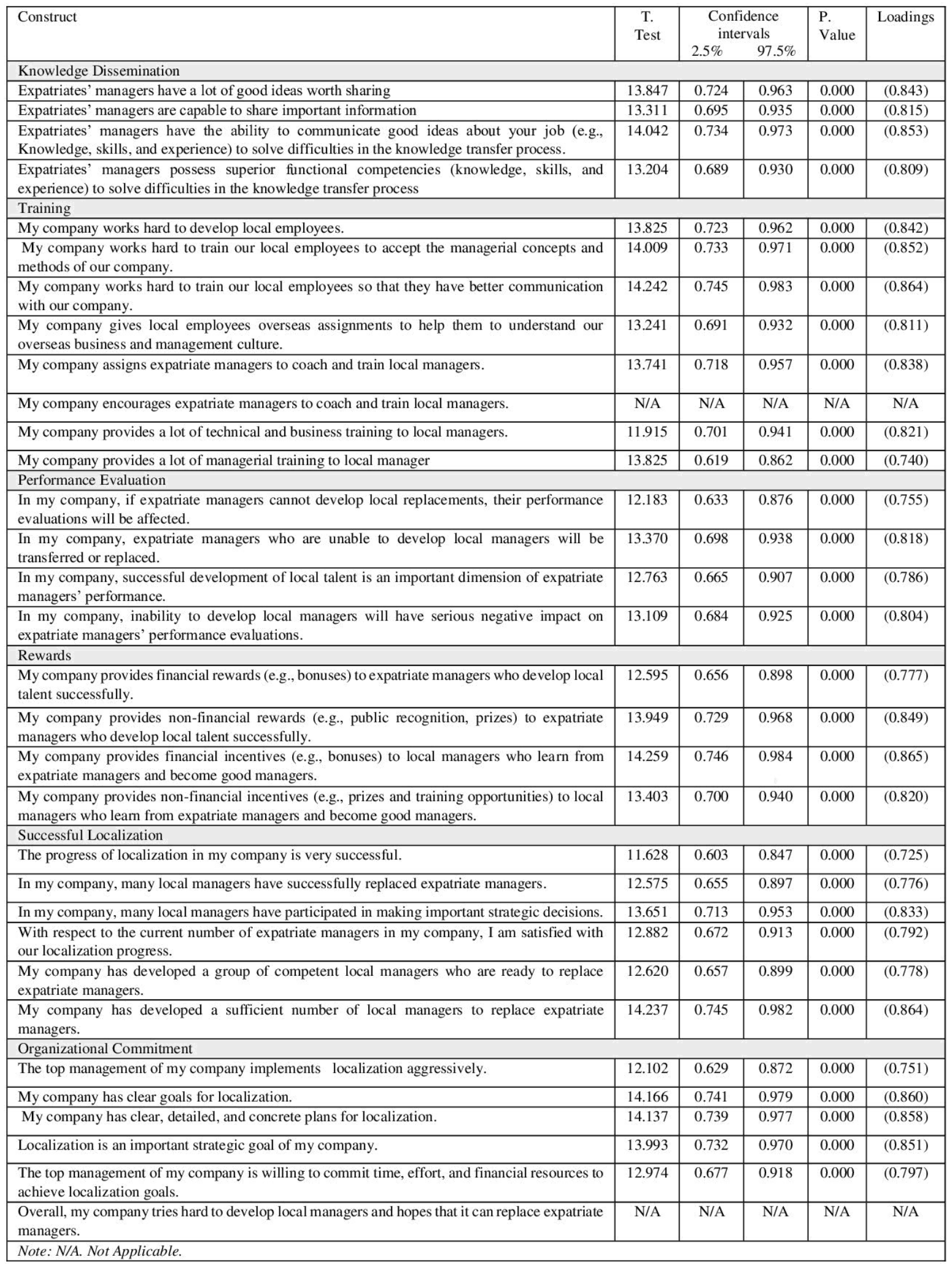

